Available online on 15.07.2018 at http://jddtonline.info
Journal of Drug Delivery and Therapeutics
Open Access to Pharmaceutical and Medical Research
$\begin{gathered}\text { 2011-18, publisher and licensee JDDT, This is an Open Access article which permits unrestricted non- } \\ \text { commercial use, provided the original work is properly cited }\end{gathered}$

Open Access

Research Article

\title{
Phytochemical analysis, antimicrobial and antioxidant activity of Lophopetalum wightianum Arn. (Celastraceae)
}

\author{
Nitish A. Bharadwaj ${ }^{1}$, Karthik Udupa K.K ${ }^{1}$, Karthik $S^{1}$, Vinayaka K.S. ${ }^{2}$, Prashith Kekuda T.R. ${ }^{{ }^{*}}$ \\ ${ }^{1}$ Department of Microbiology, S.R.N.M.N College of Applied Sciences, N.E.S Campus, Balraj Urs Road, Shivamogga-577201, \\ Karnataka, India \\ ${ }^{2}$ Department of Botany, Kumadvathi First Grade College, Shikaripura-577427, Karnataka, India
}

\section{ABSTRACT}

Objectives: Lophopetalum wightianum Arn. (Celastraceae) is a lofty evergreen tree reaching around $40 \mathrm{~m}$ in height. The present study was carried out to investigate antimicrobial and antioxidant activity of leaf and bark extract of L. wightianum.

Methods: The shade dried and powdered leaf and bark were extracted by maceration process using methanol. Extracts were screened for phytoconstituents present by standard protocols. Antibacterial and antifungal activity of extracts was evaluated by agar well diffusion and poisoned food technique respectively. Antioxidant activity was determined by DPPH radical scavenging and ferric reducing assays.

Results: Phytochemicals viz. alkaloids, flavonoids, sterols, saponins and triterpenoids were detected in both leaf and bark extracts. Inhibitory activity against test bacteria of bark extract was marked than leaf extract. Bark extract displayed more or less similar activity against test bacteria with slightly higher activity against Salmonella typhimurium and Shigella flexneri. Leaf extract was more effective against Bacillus cereus while other bacteria were inhibited to more or less similar extent. In antifungal activity, leaf extract showed highest inhibitory against Bipolaris sp. than A. niger. Bark extract showed more or less similar antifungal activity against $A$. niger and Bipolaris sp. Bark extract scavenged DPPH radicals more efficiently with $\mathrm{IC}_{50}$ value $7.03 \mu \mathrm{g} / \mathrm{ml}$ than leaf extract which scavenged radicals with $\mathrm{IC}_{50}$ value of $24.64 \mu \mathrm{g} / \mathrm{ml}$. Reducing potential exhibited by bark extract was higher when compared to leaf extract.

Conclusion: Overall, bark extract displayed marked antimicrobial and antioxidant potential. The plant is shown to contain bioactive principles with activity against pathogenic microorganisms and free radicals that cause oxidative damage.

Key words: Lophopetalum wightianum, Maceration, Phytochemical, Antimicrobial, Antioxidant

Article Info: Received 21 May, 2018; Review Completed 10 July 2018; Accepted 11 July 2018; Available online 15 July 2018

Cite this article as:

Bharadwaj NA, Karthik Udupa KK, Karthik S, Vinayaka KS, Prashith Kekuda TR, Phytochemical analysis, antimicrobial and antioxidant activity of Lophopetalum wightianum Arn. (Celastraceae), Journal of Drug Delivery and Therapeutics. 2018; 8(4):302-307 DOI: http://dx.doi.org/10.22270/iddt.v8i4.1796

*Address for Correspondence:

Dr. Prashith Kekuda T.R., Department of Microbiology, S.R.N.M.N College of Applied Sciences, N.E.S Campus, Balraj Urs Road, Karnataka, India

\section{INTRODUCTION}

Plants are an integral and indispensable part of daily life. Since time immemorial plants have been utilized for various human needs viz. food, shelter, cloths, spices, dyes and medicine. Traditional medicinal systems that are based on plants are widely practiced in several countries worldwide. Plant based medicines have been extensively used in developing and underdeveloping countries. Ayurveda, Siddha, Unani and Traditional Chinese Medicine utilize plants as a remedy for various ailments. Many drugs such as quinine, artemisinin, codeine, vincristine, vinblastine, digitoxin, morphine and aspirin are from plant origin. Natural products, their derivatives and analogues represent a majority of drugs that are in clinical use $\mathrm{e}^{1-7}$. 
Lophopetalum wightianum Arn., belonging to the family Celastraceae, is a lofty evergreen tree reaching around $40 \mathrm{~m}$ in height. The plant is common in dense evergreen forests. The leaves are opposite, up to $15 \times 7 \mathrm{~cm}$, elliptic broadly, rounded at base, apex is acute, estipulate. Flowers are disc shaped, approximately $12 \mathrm{~mm}$ across and found in axillary or terminal paniculate cymes, initially cream colored but turn scarlet red on maturity. Fruit is a 3-valved woody capsule, triangular, tightly packed with many seeds and tapers at both ends. Seeds are thin and are broadly winged on all sides. The timber of the plant is used for the purpose of house building, The present study was carried out with the objective of determining antimicrobial and antioxidant activity of leaf and bark extract of L. wightianum.

\section{MATERIALS AND METHODS}

\section{Collection of plant}

The plant was collected at Haniya, Hosanagara Taluk, Shivamogga district, Karnataka during December 2017 and authenticated by Dr. Vinayaka K.S, KFGC, Shikaripura.

\section{Extraction}

The leaf and bark were washed, dried under shade, powdered and extracted by maceration process. The powders were left in methanol solvent in separate containers for a period of 48 hours followed by filtration initially through 4-fold muslin cloth and later through Whatman filter paper No. 1. The filtrates were evaporated to dryness at room temperature in order to obtain leaf and bark extracts ${ }^{\mathbf{1 0}}$.

\section{Phytochemical analysis}

The crude leaf and bark extracts were subjected for preliminary phytochemical analysis for the detection of alkaloids, flavonoids, tannins, saponins, sterols, triterpenoids and glycosides by standard phytochemical tests $^{11-14}$.

\section{Antibacterial activity of leaf and bark extract}

Agar well diffusion method was employed to evaluate antibacterial activity of leaf and bark extract $(20 \mathrm{mg}$ extract/ml of DMSO) of L. wightianum against test bacteria viz. Bacillus cereus, Salmonella typhimurium, Escherichia coli and Shigella flexneri. Zone of inhibition formed around the wells was recorded after an incubation of 24 hours. Streptomycin was used as reference standard. The presence of inhibition zones was considered positive for antibacterial activity of extracts ${ }^{10}$.

\section{Antifungal activity of leaf and bark extract}

Poisoned food technique was carried out to evaluate antifungal efficacy of leaf and bark extract of $L$. wightianum against two seed-borne fungi viz. Aspergillus niger and Bipolaris species. Test fungi were inoculated at the centre of control and poisoned $(1 \mathrm{mg}$ extract/ml of medium) potato dextrose agar medium. The extent of inhibition of mycelial growth (\%) was calculated by using the formula:
Inhibition of mycelial growth $(\%)=(\mathrm{Dc}-\mathrm{Dt} / \mathrm{Dc}) \mathrm{x}$ 100 , where 'Dc' denotes the diameter of fungal colonies (in $\mathrm{cm}$ ) in control plates and ' $\mathrm{Dt}$ ' refers to the diameter of fungal colonies (in $\mathrm{cm}$ ) in poisoned plates ${ }^{\mathbf{1 0}}$.

\section{DPPH free radical scavenging activity}

The scavenging efficacy of various concentrations (12.5 - $200 \mu \mathrm{g}$ of extract $/ \mathrm{ml}$ of methanol) of leaf and bark extracts of $L$. wightianum was investigated on the basis of the scavenging effect against DPPH radicals ${ }^{\mathbf{1 0}}$. Ascorbic acid was used as reference antioxidant. Scavenging potential of leaf and bark extracts and ascorbic acid was determined using the formula:

Scavenging activity $(\%)=($ Ac - At $/$ Ac $) \times 100$, where 'Ac' and 'At' denotes the absorbance of DPPH control and absorbance of DPPH in presence of extract/ascorbic acid respectively. $\mathrm{IC}_{50}$ value (concentration of extract/ascorbic acid required to scavenge $50 \%$ of free radicals) was calculated.

\section{Ferric reducing activity}

The ferric reducing efficacy of various concentrations

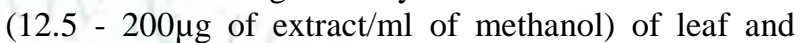
bark extracts of $L$. wightianum was investigated ${ }^{\mathbf{1 0}}$. Ascorbic acid was used as reference antioxidant. An increase in the absorbance with the increase of concentration indicated reducing ability of extract/ascorbic acid.

\section{Statistical analysis}

Experimental analyses were conducted in triplicates $(n=3)$. The results are represented as Mean \pm Standard deviation (S.D). $\mathrm{IC}_{50}$ values (for $\mathrm{DPPH}$ assay) were obtained by linear regression analysis using Origin (Data Analysis and Graphing) Software version 7.0 for windows.

\section{RESULTS AND DISCUSSION}

\section{Phytoconstituents detected in leaf and bark extracts} of L. wightianum

Plants produce a number of secondary metabolites that are distributed in various parts of plants viz. roots, leaves, flower, fruits and seeds. Phytoconstituents such as alkaloids, polyphenolic compounds and terpenoids have been shown to possess a myriad of biological activities. Hence, it is important to detect the presence of phytochemicals in plant extracts. Standard phytochemical tests detect the presence of various phytochemicals viz. alkaloids, flavonoids, sterols, saponins, triterpenoids, glycosides, and tannins present in the plant extracts ${ }^{13,15,16,17}$. In our study, preliminary phytochemical analysis detected the presence of all phytochemicals except glycosides in leaf extract of $L$. wightianum. 
Table 1: Phytoconstituents detected in leaf and bark extracts

\begin{tabular}{|l|c|c|}
\hline Phytochemical & Leaf extract & Bark extract \\
\hline Alkaloids & + & + \\
\hline Flavonoids & + & + \\
\hline Sterols & + & + \\
\hline Glycosides & - & - \\
\hline Saponins & + & + \\
\hline Triterpenoids & + & + \\
\hline Tannins & + & - \\
\hline \multicolumn{2}{|c|}{ '+' Detected; '-' Not detected } \\
\hline
\end{tabular}

In bark extract, phytochemicals viz. alkaloids, flavonoids, sterols, saponins and triterpenoids were detected while glycosides and tannins were not detected (Table 1).

Antibacterial activity of leaf and bark extracts of $\boldsymbol{L}$. wightianum
Immense interest in scientific community on antibacterial potential of plant extracts and plant metabolites arose as a consequence of drawbacks such as high cost, side effects and development of resistance in pathogenic bacteria that are associated with the use of antibiotics especially in an indiscriminate way. Several studies have shown that crude solvent extracts and purified compounds from plants exhibit marked antibacterial activity even against resistant strains of pathogenic bacteria ${ }^{\mathbf{1 0} 15,18-22}$. In the present study, both leaf and bark extracts exhibited inhibition of test bacteria with varied results. Among extracts, bark extract was more effective in inhibiting test bacteria when compared to leaf extract which was evidenced by the formation of wider zones of inhibition. Leaf extract was effective against $B$. cereus to high extent than other test bacteria. Inhibitory activity of bark extract was almost similar against test bacteria. DMSO did not inhibit test bacteria. Reference antibiotic caused marked inhibition of test bacteria when compared to leaf and bark extracts (Table 2 and Figure 1).

Table 2: Antibacterial activity of leaf and bark extract of $\boldsymbol{L}$. wightianum

\begin{tabular}{|l|c|c|c|c|}
\hline \multirow{2}{*}{ Test bacteria } & \multicolumn{4}{|c|}{ Zone of inhibition in cm } \\
\cline { 2 - 5 } & Leaf extract & Bark extract & DMSO & Antibiotic \\
\hline B. cereus & $1.40 \pm 0.00$ & $2.10 \pm 0.00$ & $0.00 \pm 0.00$ & $3.00 \pm 0.00$ \\
\hline S. typhimurium & $1.20 \pm 0.00$ & $2.23 \pm 0.05$ & $0.00 \pm 0.00$ & $3.13 \pm 0.05$ \\
\hline S. flexneri & $1.23 \pm 0.00$ & $2.20 \pm 0.00$ & $0.00 \pm 0.00$ & $3.30 \pm 0.00$ \\
\hline E. coli & $1.20 \pm 0.00$ & $2.00 \pm 0.00$ & $0.00 \pm 0.00$ & $3.53 \pm 0.05$ \\
\hline
\end{tabular}
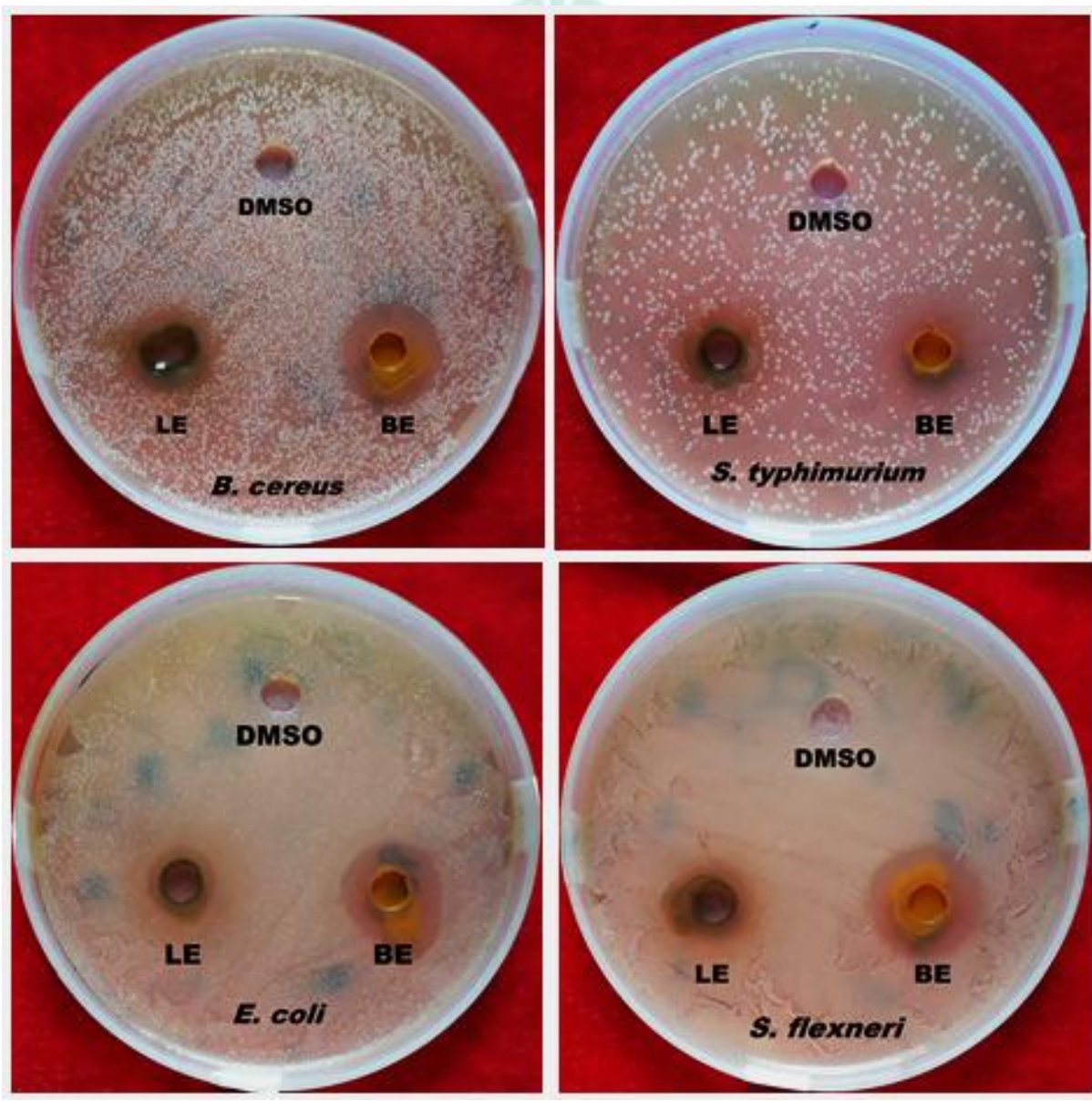

Figure 1: Inhibition of test bacteria by leaf and bark extract of $L$. wightianum 
Antifungal activity of leaf and bark extracts of $L$. wightianum

Management of phytopathogenic fungi is usually done by the use of synthetic fungicides. Interest in natural products with antifungal activity is intensified because of several drawbacks associated with the use of fungicides. Seed-borne fungi are known to cause severe effects on germination of seeds and emergence of seedlings. It is shown from several studies that extracts from higher plants are shown to be promising alternatives for fungicides ${ }^{23-26}$. Both leaf and bark extract of L. wightianum were shown to display inhibition of mycelial growth of test fungi as revealed by considerable reduction ( $>50 \%$ inhibition) in the size of colonies in poisoned plates (Table 3 and Figure 2). Bark extract displayed marked antifungal activity than leaf extract. Leaf extract exhibited marked inhibition of Bipolaris sp. (67.44\%) when compared to its inhibitory activity against $A$. niger (60\%). Bark extract exhibited more or less similar inhibition of both fungi $(>70 \%)$.

Table 3: Colony diameter of test fungi in control and poisoned plates

\begin{tabular}{|l|c|c|}
\hline \multirow{2}{*}{$\begin{array}{c}\text { Extract/ } \\
\text { Control }\end{array}$} & \multicolumn{2}{|c|}{ Colony diameter of test fungi in $\mathbf{~ c m}$} \\
\cline { 2 - 3 } Control niger & Bipolaris $\mathbf{s p .}$ \\
\hline Leaf extract & $5.53 \pm 0.05$ & $4.70 \pm 0.00$ \\
\hline Bark extract & $2.23 \pm 0.05$ & $1.53 \pm 0.05$ \\
\hline
\end{tabular}
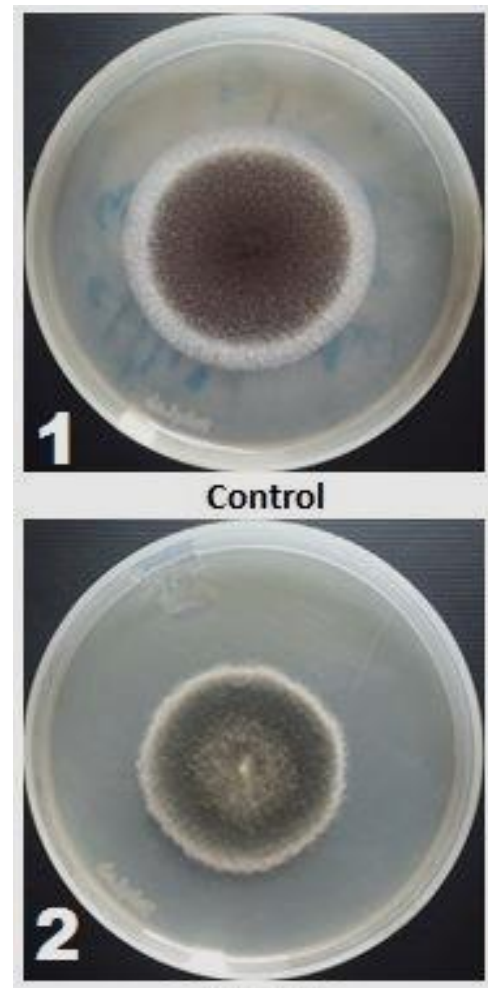

Control

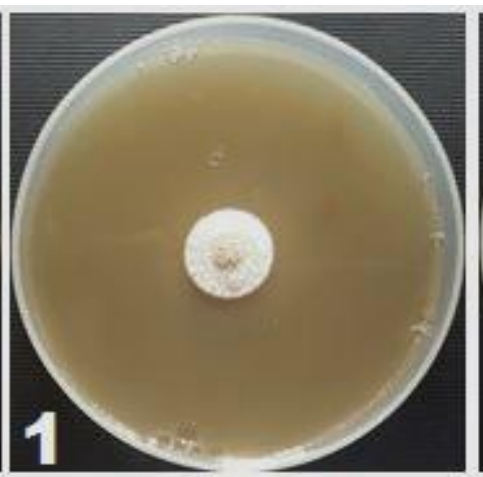

Bark extract

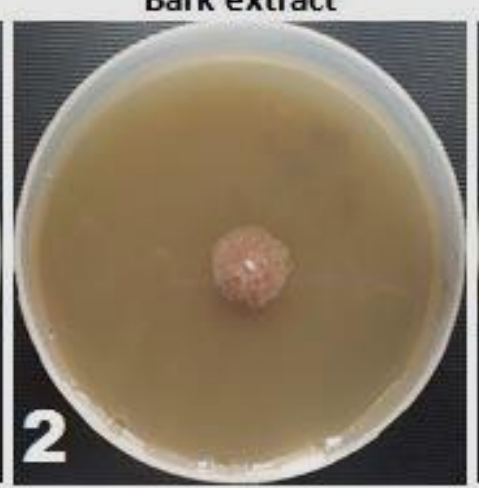

Bark extract

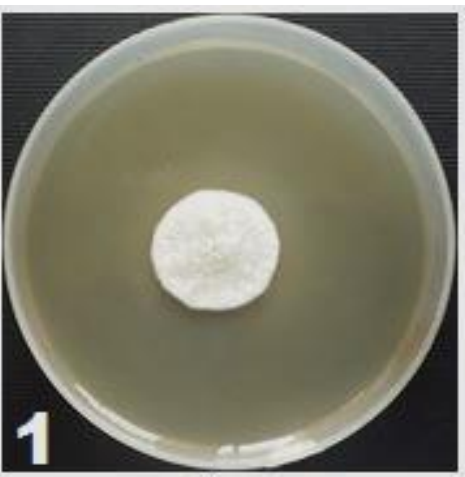

Leaf extract

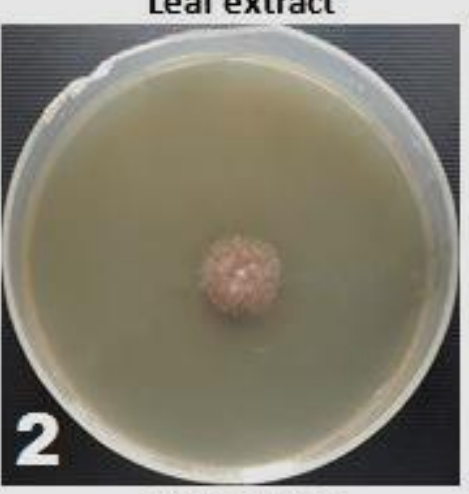

Leaf extract

Figure 2: Growth of fungi (1-A. niger; 2-Bipolaris sp.) in control and poisoned plates

DPPH radical scavenging activity of leaf and bark extracts of $L$. wightianum

Scavenging of free radicals is one of the ways of determining antioxidant activity of samples including crude solvent extracts and purified compounds. Among various in vitro methods, the method that involves scavenging of stable, nitrogen centred, organic free radical DPPH is one of the most widely used methods owing to its simplicity, rapidness and reproducibility of results ${ }^{10,27-30}$. In this study, the efficacy of different concentrations of leaf and bark extracts of $L$. wightianum to scavenge free radicals was investigated by DPPH radical scavenging assay. Both extracts scavenged DPPH radicals efficiently in a dose dependent manner (Figure 3). Bark extract displayed promising scavenging of DPPH radicals with $\mathrm{IC}_{50}$ value of $7.03 \mu \mathrm{g} / \mathrm{ml}$ when compared to leaf extract which scavenged radicals with $\mathrm{IC}_{50}$ value of $24.64 \mu \mathrm{g} / \mathrm{ml}$. A scavenging activity of $>50 \%$ was observed at extract concentrations of $12.5 \mu \mathrm{g} / \mathrm{ml}$ and $50 \mu \mathrm{g} / \mathrm{ml}$ of bark extract and leaf extract respectively. A scavenging activity of $>90 \%$ was displayed by extract concentrations viz. $100 \mu \mathrm{g} / \mathrm{ml}$ and $200 \mu \mathrm{g} / \mathrm{ml}$ of bark extract and leaf extract respectively. Scavenging potential of ascorbic acid $\left(\mathrm{IC}_{50}\right.$ value $\left.6.12 \mu \mathrm{g} / \mathrm{ml}\right)$ was slightly higher than that of leaf extract.

\section{Ferric reducing activity of leaf and bark extracts of L. wightianum}

Reducing potential serves as an indication of antioxidant activity of a substance and the reducing ability is due to the presence of reductones in it. In ferric reducing assay, the presence of reductants (antioxidants) in the extracts causes reduction of $\mathrm{Fe}^{+3}$ to $\mathrm{Fe}^{+2}$ by donating an electron. Ferric reducing assay is widely used to evaluate antioxidant activity of plant extracts ${ }^{10,27,31-34}$. In the present study, we measured the direct reduction of 
$\mathrm{Fe}^{+3}(\mathrm{CN})_{6}$ to $\mathrm{Fe}^{+2}(\mathrm{CN})_{6}$ to evaluate the reducing power of leaf and bark extracts by measuring the absorbance that results due to the formation of Perl's Prussian blue complex upon addition of excess of ferric ions $\left(\mathrm{Fe}^{+3}\right)$. An increase in absorbance at $700 \mathrm{~nm}$ on increase in extract concentration was observed which indicated the reducing property of leaf and bark extracts (Figure 4). The reducing property of ascorbic acid and extracts was in the order: ascorbic acid > bark extract > leaf extract.

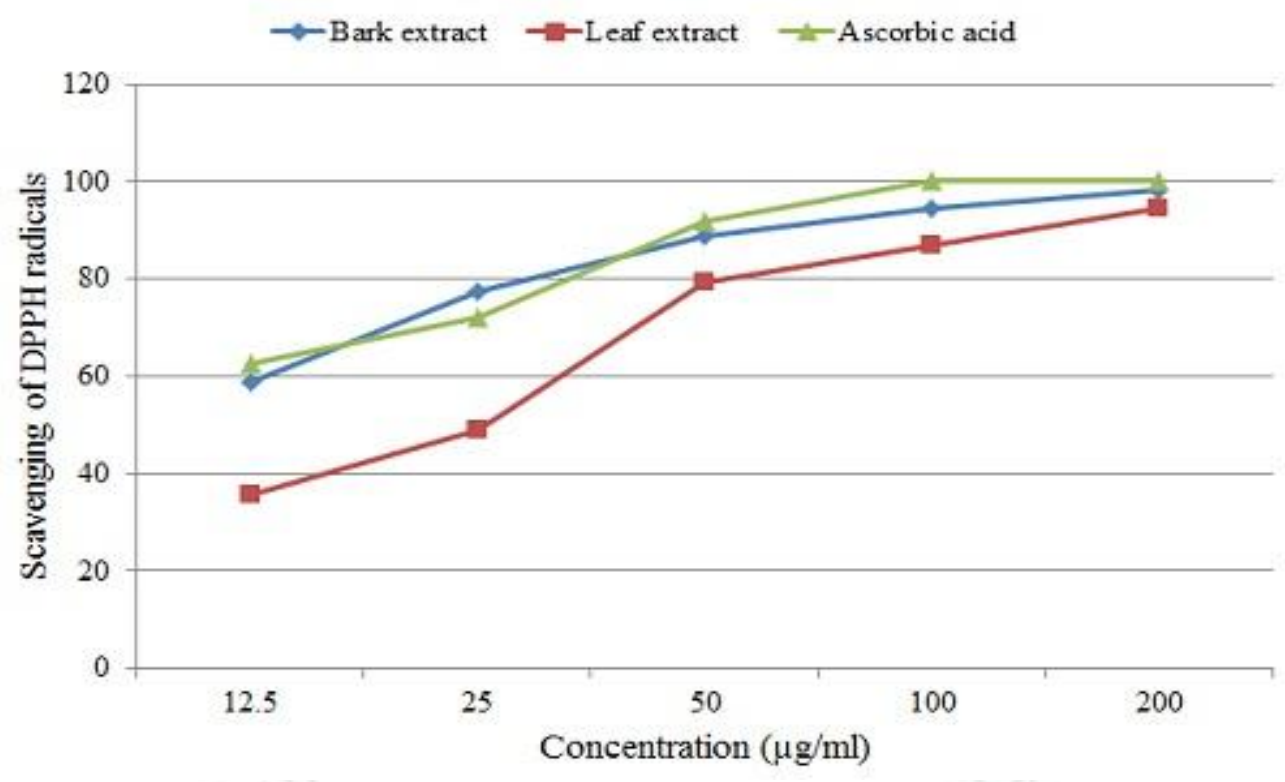

Figure 3: DPPH radical scavenging activity of leaf and bark extracts of $L$. wightianum

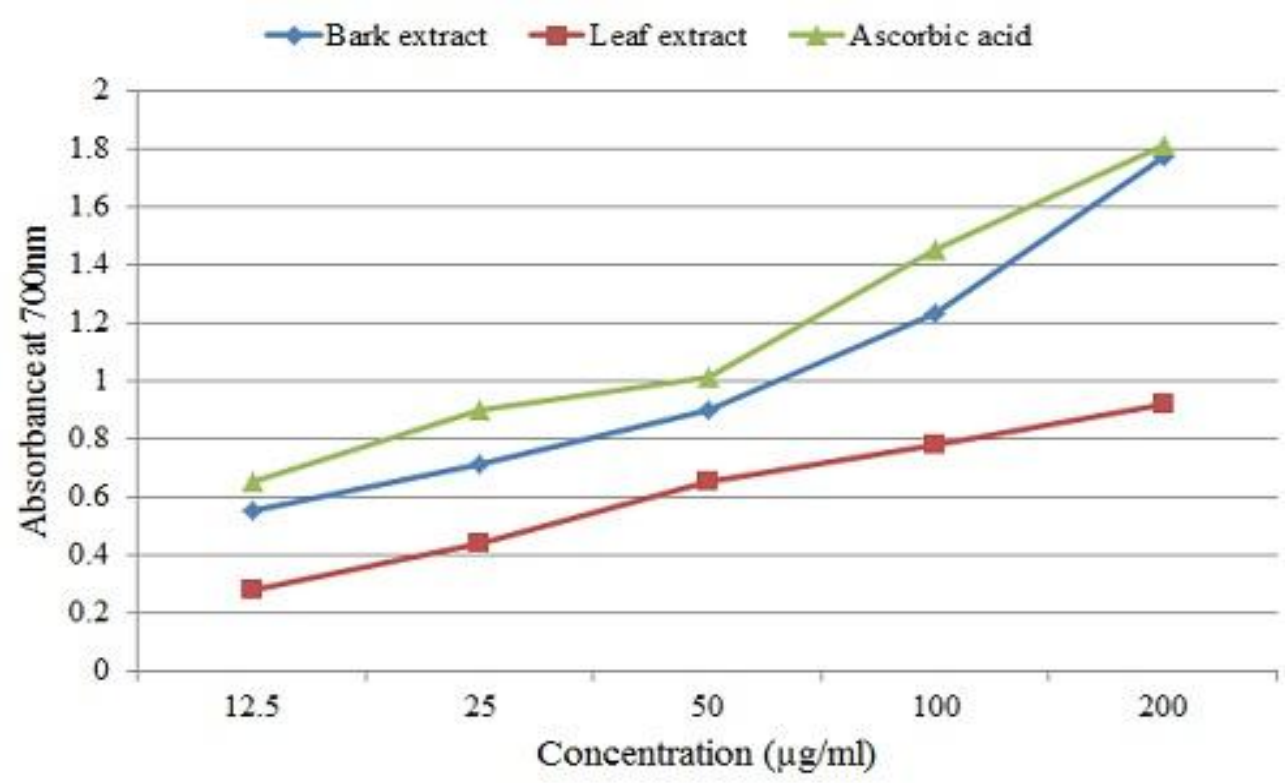

Figure 4: Ferric reducing activity of leaf and bark extracts of $L$. wightianum

\section{CONCLUSION}

Among extracts, bark extract displayed marked antibacterial, antifungal and antioxidant activities. The observed activities could be ascribed to the presence of phytochemicals such as alkaloids, flavonoids, sterols, saponins and triterpenoids that have been detected in extracts. The plant can be used to develop formulations effective against pathogenic organisms and free radical induced oxidative damage. Further studies are to be carried out in order to purify active principles from the plant and investigate their biological potentials.

\section{ACKNOWLEDGEMENTS}

Authors thank Head of the department of Microbiology and Principal, S.R.N.M.N College, Shivamogga for the facilities provided. Authors also thank N.E.S, Shivamogga for the moral encouragement.

Sources of funding: None

Conflicts of interest: None declared 


\section{REFERENCES}

1. Ravishankar B, Shukla VJ, Indian systems of medicine: A brief profile, Afr J Trad CAM, 2007; 4(3):319-337.

2. Teron R, Borthakur SK, Traditional knowledge relating to use of flora and fauna as indicators in predicting annual seasons among Karbi tribe of Assam, Indian J Tradit Know, 2009; 8(4):518-524.

3. Zhang J, Wider B, Shang H, Li X, Ernst E, Quality of herbal medicines: Challenges and solutions, Complementary Therapies in Medicine, 2012; 20(1-2):100-106.

4. Thillaivanan S, Samraj K, Challenges, constraints and opportunities in herbal medicines - A review, International Journal of Herbal Medicine, 2014; 2(1):21-24.

5. Quiroz D, Sosef M, Andel T, Why ritual plant use has ethnopharmacological relevance, J Ethnopharmacol, 2016; 188:48-56.

6. Singh R, Medicinal plants: A review, Journal of Plant Sciences, 2015; 3:50-55

7. Amuka O, Mulei JM, Gatwiri BP, A brief ethnbotanical survey of some medicinal plants used by the Kanjoo community in Meru, Advances in Biotechnology and Microbiology, 2017; 5(1):555654.

8. Punekar SA, Lakshminarasimhan P, Flora of Anshi national park, Western Ghats- Karnataka, Biosphere Publications, Pune, India, 2011, Pp 152-153.

9. Bhat GK, Flora of South Kanara (Dakshina Kannada and Udupi districts of Karnataka), Aakriti Prints, Mangalore, India, 2014, Pp 418-419.

10. Raghavendra HL, Kekuda PTR, Akarsh S, Ranjitha MC, Ashwini HS, Phytochemical analysis, antimicrobial and antioxidant activities of different parts of Pleocaulus sessilis (Nees) Bremek (Acanthaceae), Int J Green Pharm, 2017; 11(2):98-107.

11. Tiwari P, Kumar B, Kaur M, Kaur G, Kaur H, Phytochemical screening and extraction: A review, Internationale Pharmaceutica Sciencia, 2011; 1(1):98-106.

12. Ajayi IA, Ajibade $\mathrm{O}$, Oderinde RA, Preliminary phytochemical analysis of some plant seeds, Res J Chem Sci, 2011; 1(3):58-62.

13. Pandey A, Tripathi S, Concept of standardization, extraction and pre phytochemical screening strategies for herbal drug, J Pharmacogn Phytochem, 2014; 2(5):115-119.

14. Santhi K, Sengottuvel R, Qualitative and quantitative phytochemical analysis of Moringa concanensis Nimmo, Int J Curr Microbiol App Sci, 2016; 5(1):633-640.

15. Cowan MM, Plant products as antimicrobial agents, Clin Microbiol Rev, 1999; 12(4):564-582.

16. Saxena M, Saxena J, Nema R, Singh D, Gupta A, Phytochemistry of medicinal plants, J Pharmacogn Phytochem, 2013; 1(6):168-182.

17. Tiwari R, Rana CS, Plant secondary metabolites: a review, International Journal of Engineering Research and General Science, 2015; 3(5):661-670.

18. Chang ST, Chen PF, Chang SC, Antibacterial activity of leaf essential oils and their constituents from Cinnamomum osmophloeum, J Ethnopharmacol, 2001; 77(1):123-127.
19. Freile ML, Giannini F, Pucci G, Sturniolo A, Rodero L, Pucci O, Balzareti V, Enriz RD, Antimicrobial activity of aqueous extracts and of berberine isolated from Berberis heterophylla, Fitoterapia, 2003; 74(7-8):702-705.

20. Wallace RJ, Antimicrobial properties of plant secondary metabolites, Proc Nutr Soc, 2004; 63(4):621-629.

21. Cushnie TP, Lamb AJ, Antimicrobial activity of flavonoids, Int J Antimicrob Agents, 2005; 26(5):343-356.

22. Compean KL, Ynalvez RA, Antimicrobial activity of plant secondary metabolites: A review, Research Journal of Medicinal Plants 2014; 8(5):204-213.

23. Farrag ESH, Moharam MHA, Ziedan EH, Effect of plant extracts on morphological and pathological potential of seedborne fungi on cucumber seeds, Int J Agric Technol, 2012; 9(1):141-149.

24. Kekuda PTR, Akarsh S, Darshini SM, Prafulla D, Raghavendra HL, Antiradical and antimicrobial activity of Atylosia lineata Wt. and Arn, Sci Technol Arts Res J, 2015; 4(3):180-183.

25. Bhardwaja J, Setha MK, Gogoi R, Evaluation of antifungal efficacy of plant extracts against seed-borne fungi Colletotrichum lindemuthianum, Int J Curr Sci, 2015; 18:4954.

26. Lakshmeesha TR, Sateesh MK, Vedashree S, Sofi MS, Antifungal activity of some medicinal plants on Soybean seedborne Macrophomina phaseolina, J Appl Pharm Sci, 2013; 3(2):84-87.

27. Chung Y, Chien C, Teng K, Chou S, Antioxidative and mutagenic properties of Zanthoxylum ailanthoides Sieb \& zucc, Food Chem, 2006; 97:418-425.

28. Marinova G, Batchvarov V, Evaluation of the methods for determination of the free radical scavenging activity by DPPH, Bulg J Agric Sci, 2011; 17:11-24.

29. Martysiak-Żurowska D, Wenta W, A comparison of ABTS and DPPH methods for assessing the total antioxidant capacity of human milk, Acta Sci Pol, 2012; 11(1):83-89.

30. Valantina RS, Neelamegam P, Selective ABTS and DPPHradical scavenging activity of peroxide from vegetable oils, International Food Research Journal, 2015; 22(1):289-294.

31. Ferreira ICFR, Baptista P, Vilas-Boas M, Barros L, Freeradical scavenging capacity and reducing power of wild edible mushrooms from northeast Portugal: Individual cap and stipe activity, Food Chem, 2007; 100:1511-1516.

32. Gulcin I, Topal F, Sarikaya SBO, Bursal E, Bilsel G, Goren AC, Polyphenol contents and antioxidant properties of Medlar (Mespilus germanica L.), Rec Nat Prod, 2011; 5(3):158-175.

33. Jayanthi P, Lalitha P, Reducing power of the solvent extracts of Eichhornia crassipes (Mart.) Solms, Int J Pharm Pharm Sci, 2011; 3(3):126-128.

34. Ahmed D, Khan MM, Saeed R, Comparative analysis of phenolics, flavonoids, and antioxidant and antibacterial potential of methanolic, hexanic and aqueous extracts from Adiantum caudatum Leaves, Antioxidants, 2015; 4:394-409. 